\title{
力学刺激に細胞は何 を感じるか \\ What is the Sensing Mechanism of Cells under Mechanical Stimuli?
}

\section{1. カ学刺激を感知する細胞}

日常何げなく生活している我々であ

るが, さて身体はどのような力を感じ 取っているのであろうかと考えてみる と，力のセンサなしでは我々の生活は 成り立たないことにすぐ気付くであろ う。身体の中にあって力学的な刺激を 感知している代表的な細胞に登場して もらうことにしよう（図 1$)^{(1)(2)}$.

皮膚は物の硬さ軟らかさを圧力とし て感じるし, 速さ, 加速度, 変形など も感知している。図1（a）に示した 皮膚のセンサ細胞はメルケル細胞で, 表皮の比較的浅い領域に存在してい る。図をみるとアンテナ状の突起を出 し, この突起の変形によっていかにも 感度よく力を感知するように思われ る。このようなセンサ細胞に共通して いるのは，外部から刺激がセンサ部に 加わると細胞膜の状態が変化した後, 細胞内の $\mathrm{K}^{+} や \mathrm{Ca}^{2+}$ などのイオン濃 度が変わり, 神経に信号を送る伝達物 質が対側から産生される機構である。 すなわち, 力学刺激は化学信号, 電気 信号へと変換されて我々は力を感知し ているわけである。実は皮膚には，こ の他にもマイスネル小体, パチ二小 体, ルフィ二終末と呼ばれる力学セン サがある。このような細胞あるいは小 体を機械受容器 (mechanoreceptor) という。

図1（b）の例は内耳にある外有毛 細胞である。これは外部からの音刺激 を増幅する役目を果たしており(3)，外 有毛細胞の頭部にある聴毛と呼ばれる 突起が片持ばりのように変形すること によって力を感知し, 変換した信号を 下部の神経終末へ送り出している.

我々は力を直接感知しているという 意識をしていないが, 骨格筋の中には 筋紡錐と呼ばれるセンサがあり，絶え ず筋肉の伸びや発生する力を感知して 姿勢や運動の制御をしている.

\section{2. 化学刺激を感知する細胞}

身体の中には力学刺激だけでなく化 学的な刺激もたくさんあるわけで, 例 えば舌の表面には種々の味に応答する 味細胞，腸には基底果粒細胞などがあ り, 化学的な刺激に反応している。 れらの細胞の代表的な模式図を図 1 (c) に示す。既に述べてきた力学刺 激を感じる細胞と同じような形をして おり，頭部にセンサとなる毛状の構造 が存在し，底部から信号を伝達する物 質が産生されている。感知する対象が 異なっても細胞が同様の形態と機能を もつているのは, 生命の進化の過程で 共通の経路をたどってきている証でも あろう。

\section{3. 力学受容の不明な 細胞の例}

これまで述べてきた細胞では, 力学 的あるいは化学的刺激を受容するため のアンテナの役割をする明確な構造が 存在し, 信号の伝達も概略把握できて いる、しかしながら，血管壁の内腔側 に存在する内皮細胞では，これらの点 が明確ではないが，流れのせん断応力 や張力などの力学刺激を加えると明確 な反応を示す．図 2 (a) はウシ大動 脈由来の培養内皮細胞に $2 \mathrm{~Pa}$ のせん 断応力を 24 時間負荷したときの状態 で, 細胞の形態を決定する一つの重要 な構造成分（細胞骨格）であるアクチ ンフィラメントを染色して示してい る. 力学刺激が加わらない場合は多角 形を示すが, せん断応力のもとでは図 2 (a) のように流れの方向に沿って非 常に細長い形に変わると同時に内部の 細胞骨格構造も変わる。これは細胞同 士が接触している場合であって，細胞 が個々に接触しないようにバラバラの 状態で培養すると， せん断応力 $2 \mathrm{~Pa}$ を24 時間加えても図 2 (b) に示すよ うに流れの方向への配向がみられな 


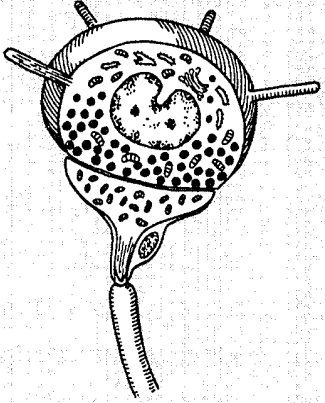

(a) 皮膚のメルケル細胞

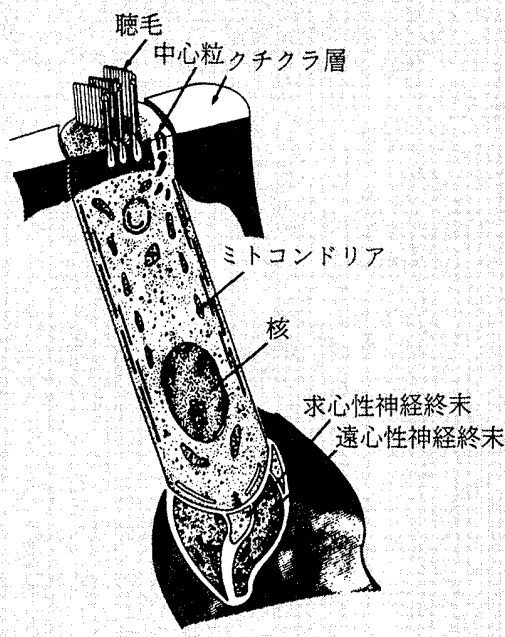

(b) 内耳の外有毛細胞

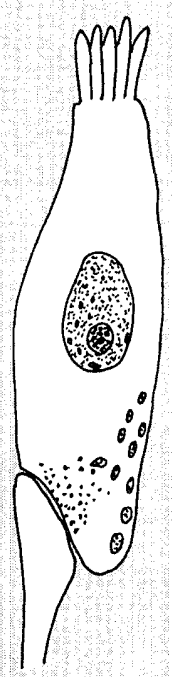

(c) 舌の味細胞

図 1 力学的および化学的刺激に対して反㐫する受容器をもった細胞

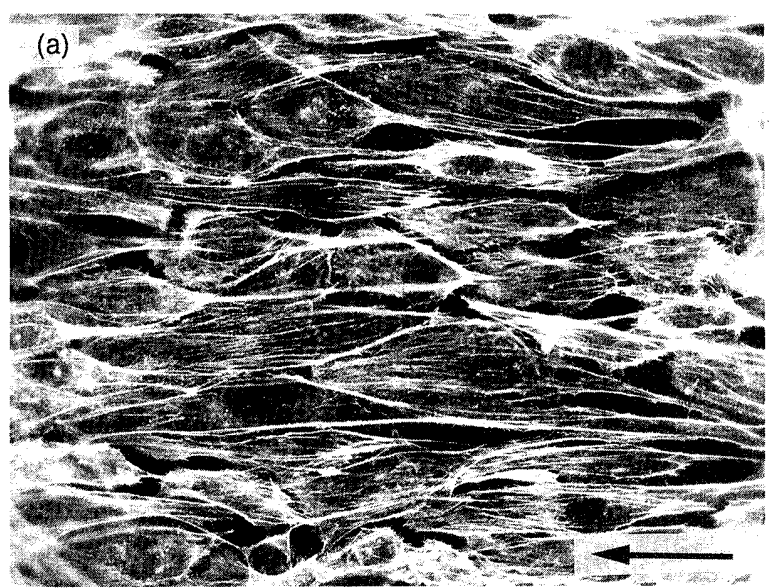

(a) 細胞同士がすべて接触している状態

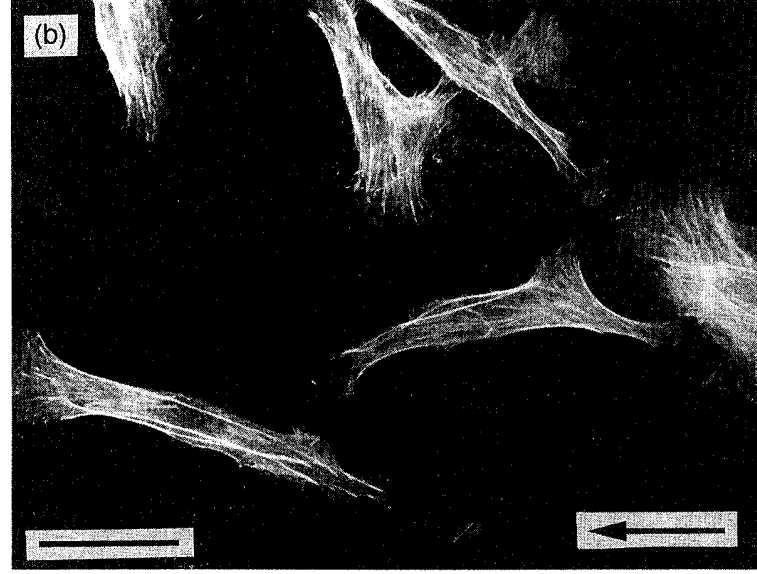

（b）細胞同士が接触しないようにバラバラにした状態

図 2 流れのせん断応力 $(2 \mathrm{~Pa})$ を 24 時間負荷した後の血管内皮細胞のようす．細胞骨格であるアクチンフィ ラメントを染色している. 矢印は流れの方向を示す. バー $=50 \mu \mathrm{m}$

い(4).なお，この場合細胞形状も培養 当初からこのように杆状を呈する。同 じ細胞なのにどうしてこのように異な る反応を示すのであろうか.内皮細胞 は力学刺激に対して種々の物質を産生 することが知られており，これらの物 質は血管壁の収縮・弛緩，あるいは血 液の凝固を制御する働きを有してい る。内皮細胞については，血液循環系 の調節という視点から关の機能が非常 に重要であるので，世界の多くの研究 者がこの領域の研究を行っている。し かしながら, 内皮細胞の力学刺激の感 知機構については現在のところ不明で ある. 力学刺激によって細胞全体が変 形するので，細胞内のいろいろな部分
がひずみを感じる可能性があるが，内 皮細胞には前述のメルケル細胞や外有 毛細胞などのようにアンテナの役割を して，はつきりと力学刺激を感知して いると考えられる構造物は存在しな い.また，細胞の接触状態によって反 応が異なり，このような点がこの領域 の研究をますます興味深いものにして いると同時に混乱させている。著者ら は, 外部の力学刺激によって細胞が変 形した際，細胞内に張り巡らされたア クチンフィラメントを通して, 張力が 細胞の核あるいは細胞が基質に接着し ている部位へ伝達され，細胞の形態変 化や機能の発現などの反応を引き起こ しているのではないかと考えている.
もちろん，この他にもいろいろな考え 方があって, 細胞膜自体に力学センサ が存在するという観点からの研究もあ る。力学刺激を受けた際の細胞の内部 の様相は複雑である。果たして, 内皮 細胞は力学刺激に対して何を感じてい るのであろうか.

\section{文、献}

（1）藤田，腸は考える，(1991），岩波新書.

(2) Weiss, L. and Greep, R.O., Histology (4th ed), (1977) McGraw-Hill.

（3）日本機械学会編，生体機械工学, (1997).

（4）片岡・医加，日本機械学会論文集 63607, C (1997), 838-845. 